Jurdimas (Jurnal Pengabdian Kepada Masyarakat) Royal

Vol. 5 No. 1, Januari 2022, hlm. 93 - 98

Available online at https://jurnal.stmikroyal.ac.id/index.php/jurdimas

\title{
SOSIALISASI PEMANFAATAN INTERNET SEHAT DAN AMAN DIKALANGAN REMAJA AGAR TERCIPTA KEMANDIRIAN BELAJAR
}

\author{
Yusli Yenni ${ }^{1 *}$, Ellbert Hutabri ${ }^{1}$ \\ ${ }^{1}$ Program Studi Teknik Informatikan, Universitas Putera Batam \\ Email: *yusliany10@gmail.com
}

\begin{abstract}
Computer information technology in helping human life is growing very rapidly. This technological develpment is also supported by internet technology which can be accessed by everyone. The development of the internet can also support the learning and teaching process. Because the internet is a computer component in a computer network that can connect these components throughout the world computer network. So from that, to support the learning process it is necessary to apply the use of the internet in a healthy and safe manner. Healthy and safe use of the internet can protect internet users to avoid dangers and crimes that occur in cyberspace or are committed online. The use of the internet among adolescents is dominated by use in social media. Therefore, teenagers need to be given an understanding of using the internet safely and healthily in order to create a good learning process. This coaching is carried out on adolescents in Pesona Rhabayu housing, Patam Lestari Village, Sekupang District, Batam. This socialization provides understanding and solutions for adolescents in using the internet wisely so that they can improve learning and be error free in using the internet so as not to damage the nation's young generation.
\end{abstract}

Keywords: internet; learning; social media;

Abstrak: Teknologi informasi komputer dalam membantu kehidupan manusia semakin berkembangan dengan sangat pesat. Perkembanan teknologi ini juga didukung dengan teknologi internet yang mana dapat diakses oleh semua orang. Perkembangan internet juga dapat mendukung dalam proses masa belajar dan mengajar. Karena internet merupakan komponen komputer dalam jaringan komputer yang dapat menghubungkan komponen tersebut di seluruh jaringan komputer dunia. Maka dari padahal tersebut untuk mendukung proses pembelajaran perlu diterapkan penggunaan internet secara sehat dan aman. Penggunaan internet secara sehat dan aman dapat melindungi para pengguna internet untuk terhindar dari bahaya dan kejahatan yang terjadi di dunia maya atau dilakukan secara online. Penggunaan internet dikalangan remaja didominasi oleh penggunaan dalam media sosial. Maka dari hal tersebut para remaja perlu diberikan pemahaman dalam menggunakan internet dengan aman dan sehat agar tercipta proses belajar yang baik. Pembinaan ini dilakukan pada remaja pada Perum Pesona Rhabayu Kelurahan Patam Lestari Kecamatan Sekupang Batam. Sosialisasi ini memberikan Pemahaman dan solusi bagi remaja dalam memanfaatkan internet dengan bijak sehingga dapat meningkatkan belajar dan bebas dari kesalahan dalam memanfaatkan internet agar tidak merusak generasi muda bangsa.

Kata kunci : internet; media sosia; pembelajaran 
Jurdimas (Jurnal Pengabdian Kepada Masyarakat) Royal

Vol. 5 No. 1, Januari 2022, hlm. 93 - 98

ISSN 2614-7912 (Print)

DOI: https://doi.org/10.33330/jurdimas.v5i1.1134

ISSN 2622-3813 (Online)

Available online at https://jurnal.stmikroyal.ac.id/index.php/jurdimas

\section{PENDAHULUAN}

Pada era globalisasi saat ini teknologi internet menghadapi perkembangan yang sangat besar dalam semua bidang yang dimana setiap prosesnya dapat membantu pekerjaan manusia. Dalam bidang pendidikan perkembangan teknologi internet juga mengalami perubahan (Darmawan, Lestari, \& Wibawati, 2019). Hal ini dilihat dari penggunaan internet yang dapat membantu dalam proses pembelajaran. Menurut data Badan Pusat Statistik (BPS) Indonesia mengalami peningkatan dalam penggunaan teknologi internet. Hal tersebut dapat dilihat dari data BPS yang dimana pada tahun 2014 sebesar 252 penduduk Indonesia sudah menggunakan teknologi internet, jika dilihat dari sisi jumlah penduduk berarti Indonesia mengalami pertumbuhan 16.2 juta pengguna, yaitu dari 71,9 juta menjadi 88,1 juta pengguna (Kristiyono, 2015).

Penggunaan internet telah banyak memberikan perubahan terhadap pola kehidupan manusia. Penggunaan internet dengan sehat dan aman merupakan komponen sangat penting yang harus diterapkan. Mengakses atau menggunakan internet dengan sehat dan aman dapat memberikan dampak yang positif bagi penggunaan (Nugraha, 2018). Pemerintah Indonesia meluncurkan suatu Program Internet Sehat dan Aman atau INSAN yang dimana berada dalam lingkup Kementerian Komunikasi Dan Informatikan Indonesia (Kemkominfo). Adapun tujuan dari program tersebut yaitu mensosialisaikan dalam peng-gunaan internet yang dapat di lakukan dengan sehat dan aman melalui pembelajaran etika berinternet secara sehat dengan melihatkan seluruh komponen masyarakat (Hidayanto \& Zidni Ilmi, 2015).

Internet sebagai media pembelajaran merupakan menggunakan internet untuk dapat mengakses informasi ataupun dalam melakukan proses transfer informasi atau data. Internet sebagai pendukung media pembelajaran karena menyediakan akses proses belajaran yang interaktif karena proses media pembelajaran dianggap lebih update dan efektif serta dapat melengkapi kebutuhan informasi khususnya yang berhubungan dengan pembelajaran tanpa kendala waktu dan tempat (Rohmawati, 2015).

Dalam memanfaatkan teknologi internet dapat mempengaruhi suatu keterampilan membaca seseorang. Selain membaca ada ketrampilan yang dapat mempengaruhi seseorang yaitu intergrasi yang dimana berbeda dengan dari sumber informasi (misalnya menghubungkan informasi dari yang berbeda halaman web) dan evaluasi informasi dengan mengevaluasi kredibilitas rekomendasi di halaman web (Walidaini \& Arifin, 2018).

Pembinaan ini dilakukan di Perumahan Pesona Rhabayu Kelurahan Patam Lestari Kecamatan Sekupang Batam. Target dari pembinaan ini adalah para remaja atau pelajar yang ada diperumahan tersebut. Para remaja yang di lakukan pembinaan berada pada umur 10-17 tahun karena pada usia tersebut para remaja disana sudah mengenal internet tetapi belum menggunakan secara optimal dan sesuai kebutuhan. Banyak para remaja disana juga menggunakan internet tidak terlalu optimal dalam proses belajar, kebanyak menggunakannya hanya untuk bermain game online. Sehingga dalam belajar mereka memerlukan bantuan pihak ketiga dalam proses belajar. Hal ini 
Jurdimas (Jurnal Pengabdian Kepada Masyarakat) Royal

Vol. 5 No. 1, Januari 2022, hlm. 93 - 98

Available online at https://jurnal.stmikroyal.ac.id/index.php/jurdimas

membuat para remaja disana tidak mandiri dalam belajar.

\section{METODE}

Kegiatan pengabdian ini akan di laksanakan di Perum Pesona Rhabayu Kelurahan Patam Lestari Kecamatan Sekupang Batam, yang akan diadakan di minggu ketiga bulan februari dan bulan maret. Adapun jumlah anggota dalam pembinaan ini 20 orang mulai dari usia 10 tahun sampai 17 tahun. Adapun metode pelaksanaannya adalah sebagai berikut:

\section{Pelaksanaan Pra Test:}

Kegiatan pelaksanaannya dilakukan dalam pembinaan ini di awali dengan memberikan pemberian Qoesioner Pra test guna memahami seberapa pahamannya para remaja dalam menggunakan internet dengan sehat, aman. Serta kegiatan ini juga mengukur tingkat pengetahuan para peserta dalam penggunaan internet dalam proses pembelajaran.

\section{Penyampaian Materi:}

Berdasarkan dari hasil yang diperoleh dalam Pra Test, maka hal yang akan dilakukan oleh pemateri akan penggarahan serta memberikan pemahaman kepada peserta untuk meningkatkan pengetahuan dan kemampuan dalam memahami penggunaan internet dengan sehat dan aman. Sehingga dapat tercipta kemandirian pembelajaran nantinya.

\section{Evaluasi Pelaksanaan Kegiatan}

Dalam kegiatan pengabdian ini akan di evaluasi setiap proses yang terjadi. Proses dalam pelaksanaan pengabdian ini sosialisasi pemanfaatan internet sehat dan aman dikalangan remaja perumahan pesoana rhabayu pesona agar tercipta kemandirian belajar. Evaluasi pelaksanaan kegiatan pembinaan ini dapat memberikan manfaat. Hal tersebut dapat dilihat dari hasil penyampaian materi yang dilakukan pada hari pertama dan pembandingkan dengan Qoesioner yang dilakukan sebelum kegiatan pengabdian dimulai.

\section{PEMBAHASAN}

\section{Manfaat internet}

Kegiatan di awali dengan pembukaan acara sosialisasi oleh ketua RW Pesona Rhabyu kelurahan Patam Lestari kecamatan Sekupang Batam, selanjutnya penyampaian manfaat internet sehat oleh narasumber pertama, hadirnya internet didunia memberikan pengaruh yang luar biasa terhadap kehidupan manusia, terlebih lagi bagi pelajar dan pendidikan. Internet sehat adalah segala sesuatu yang berkaitan dengan aktifitas menggunakan internet yang memiliki nilai positif bagi pengguna dan bagi orang lain. Internet sehat merupakan upaya atau ajakan kepada masyarakat khususnya remaja pengguna internet untuk memanfaatkan internet untuk hal-hal yang positif. Adapun maafaat internet bagi pelajar dan pendidikan adalah:

1. Sumber informasi segala jenis ilmu pengetahuan

2. Pelatihan dan pembelajaran online

3. Membaca buku digital atau akses perpustakaan online

4. Memperluas pengetahuan dan pergaulan

5. Mendukung pembelajaran mandiri/ otodidak 
Jurdimas (Jurnal Pengabdian Kepada Masyarakat) Royal

Vol. 5 No. 1, Januari 2022, hlm. 93 - 98

ISSN 2614-7912 (Print)

DOI: https://doi.org/10.33330/jurdimas.v5i1.1134

ISSN 2622-3813 (Online)

Available online at https://jurnal.stmikroyal.ac.id/index.php/jurdimas

\section{Dampak positif dan dampak negatif internet}

Internet tidak bisa lepas dari sisi negatif dan positif, Internet sebagai media komunikasi merupakan fungsi internet yang paling banyak digunakan dimana setiap pengguna internet dapat berkomunikasi dengan pengguna lainnya dari seluruh dunia (Halim, 2015). Berikut dapak positif dari penggunaan internet: Sebagai Media pertukaran data, Media untuk mencari informasi atau data, Kemudahan bertransaksi dan berbisnis dalam bidang perdagangan. Sedangkan dapak negatif dari penggunaan internet: Pornografi, Penipuan,Perjudian dll.

\section{Cara Cerdas dan Bijak Berinternet}

Penggunaan internet yang efektif adalah yang sejalan sesuai dengan kebutuhan. Misalnya sebagai seorang pelajar, internet seharusnya menjadi gudang informasi untuk mengembangkan ilmu pengetahuan. Dengan cara seperti itu internet akan menjadi teknologi yang mendorong perkembangan sumber daya manusia. Peran aktif orang tua dalam mengawasi anaknya berinternet ria juga sangat dibutuhkan, mengingat bahwa informasi yang diakses harus disesuaikan dengan usia. Anak kecil yang sudah mengenal internet harus diawasi mengingat internet menyediakan beragam jenis informasi yang tidak sehat untuk dikonsumsi oleh semua jenis usia (Putriyandari, Amran, Roisah, Komalasari, \& Yuliyana, 2018).

Pelaksaan pengabdian ini dimulai dari tahap persiapan sampai pelaksaannya, dapat kami sampaikan temuan-temuan sebagai berikut :

1. Pengabdian ini mendapat dukungan dari ketua RW Pesona Rhabyu Kelurahan Patam Lestari
Kecamatan Sekupang Batam agar program pengabdian ini dapat di laksanakan secara berskala di tahun berikutnya.

2. Untuk materi dalam pembinaan pengabdian ini akan diberikan berdasarakan pembahasan dengan menggunakan bahasa yang mudah dipahami oleh para peserta. Tujuan agar para peserta dapat menambah wawasan dan pengetahuan akan penggunaan internet dengan sehat dan kejahatan-kejahatan yang ada di dunia internet juga.

3. Situasi dan kondisi pembinaan yang dilakukan sangatlah kondusif serta memberikan kenyaman bagi peserta pembinaan di perumahan Pesona Rhabyu Kelurahan Patam Lestari Kecamatan Sekupang Batam

4. Para peserta dapat mengetahui kelebihan dan kerugian dalam menggunakan internet. Pemahaman yang di dapat juga para peserta mengetahui cara menggunakan internet dengan sehat serta kejahatan-kejahatan apa yang terjadi di dunia internet.

5. Setelah dilakukan pembinaan ini meskipun belum sempurna para peserta mampu mengetahui bagaimana menggunakan internet dengan sehat serta apa saja kejahatan yang dapat terjadi dengan menggunakan internet. Hal ini nantinya akan berlangsung ketahapan pembelajaran dalam menggunakan internet berikutnya.

Pada kegiatan pengabdian yang telah dilakukan pada masyarakat khusus terhadap anak-anak dalam perumahan pesona rhabayu ini dengan hasil yang sangat memenuhi dampak yang positif terutama pada peserta pengabdian ini. Tidak hanya para peserta namun juga 
tim dosen pengabdian juga di berikan dampak positif dari hasil pengabdian ini. Adapun hasil yang di peroleh dalam kegiatan pengabdian pembinaan ini dapat dilihat dari hal-hal sebagai berikut:

1. Suksesnya menjalin kerjasama yang di lakukan antara masyarakat pesona rhabayu dengan tim dosen universitas putera batam yang di lakukan secara terus menerus atau berkelanjutan.

2. Untuk penilaian akan dilihat dari setiap respon para peserta kegiatan dalam program pengabdian ini. Dimana hasilnya akan di observasi selama kegiatan berlangsung dengan cara melakukan diskusi yang berkaitan dengan materi pembahasan.

3. Pengabdian ini meningkatkan ketrampilan dan pengetahuan setelah mendapatkan pelatihan keterampilan peserta akan dinilai dari tugas-tugas sebagai contohnya mengetahui cara penggunakaan internet dengan baik dan pemahaman akan bahaya dalam penggunakaan internet bagi anak-anak perumahan pesona rhabyu kelurahan lestari kecamatan sekupang batam.

4. Para peserta program pengabdian ini memili latar belakang Pendidikan yang berbeda yang mengikut pelatihan ini mampu menggunakan internet dengan baik dan sebagai media pembelajaran.

Dalam pengabdian ini para peserta pembinaan juga diajarkan internet sehat dan mengetahui kejahatan-kejahatan dalam penggunaan internet bagi kalangan anak-anak sampai remaja di perumahan pesona rhabyu. Pembahasan ini di mulai dengan penyampaian tentang penggunaan internet sehat serta memberikan penjelasan tentang kejahatan-kejahatan yang ada di internet.

\section{KESIMPULAN}

Hasil dari melakukan kegiatan pengabdian ini maka diperoleh para anak-anak pada perumahan pesona rhabyu dapat di Tarik kesimpulan bahwa pembinaan ini memberikan pengetahui kepada para peserta dalam penggunakaan internet dengan sehat dalam pembelajaran maupun dalam penggunaan sehari-hari. Serta pembinaan ini juga memberikan pengetahuan kepada para peserta untuk bahaya kejahatan dalam internet jika tidak menggunakan media internet dengan bijak. Tidak hanya dari segi kemampuan para peserta juga dapat menyalur ilmunya kepada anak-anak yang lain nantinya.

\section{DAFTAR PUSTAKA}

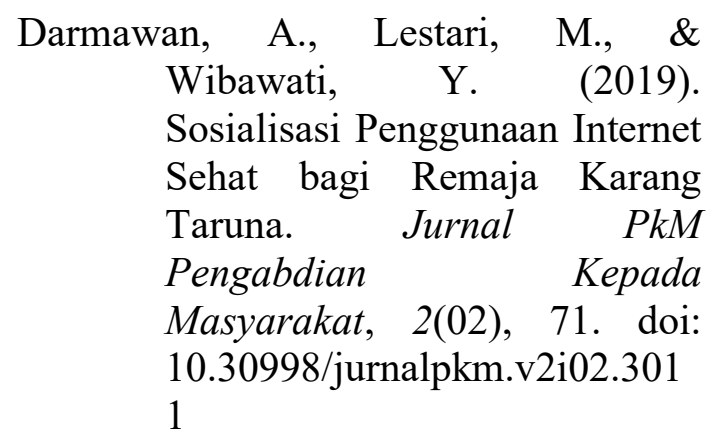

Halim, N. A. (2015). Penggunaan Media Internet di Kalangan Remaja Untuk Mengembangkan Pemahaman Keislaman. Jurnal RISALAH, 26(3), 132-150.

Hidayanto, F., \& Zidni Ilmi, M. (2015). Pentingnya internet sehat. Jurnal Inovasi Dan Kewirausahaan, 4(1), 21-24. 
Jurdimas (Jurnal Pengabdian Kepada Masyarakat) Royal

Vol. 5 No. 1, Januari 2022, hlm. 93 - 98

Kristiyono, J. (2015). Budaya Internet: Perkembangan Teknologi Informasi Dan Komunikasi Dalam Mendukung Penggunaan Media Di Masyarakat. Scriptura, 5(1), 23-30. doi: 10.9744/scriptura.5.1.23-30

Nugraha, A. (2018). Edukasi Internet Sehat Dan Aman. Majalah Ilmiah "PELITA ILMU," 1(1), 22-32.

Putriyandari, R., Amran, A., Roisah, R., Komalasari, Y., \& Yuliyana, W. (2018). Implementasi Pemanfaatan Media Sosial dalam Meningkatkan Pendapatan di Lembaga Belajar
SMART CLUB BANDUNG. Jurnal Abdimas Bsi, 1(1), 15.

Rohmawati, A. (2015). Efektivitas Pembelajaran. Jurnal Pendidikan Usia Dini, 9(1), 15-32. doi: https://doi.org/10.21009/JPUD. 091.02

Walidaini, B., \& Arifin, A. M. M. (2018). Pemanfaatan Internet Untuk Belajar Pada Mahasiswa. Jurnal Penelitian Bimbingan Dan Konseling, 3(1). doi: 10.30870/jpbk.v3i1.3200 